\title{
PENGARUH PENDIDIKAN KEWIRAUSAHAAN TERHADAP MINAT MAHASISWA UNTUK BERWIRAUSAHA PADA MAHASISWA PENDIDIKAN EKONOMI UNIVERSITAS PENDIDIKAN GANESHA
}

\author{
Ni Luh Wahyuni Widya Putri \\ Jurusan Pendidikan Ekonomi, Fakultas Ekonomi \\ Universitas Pendidikan Ganesha Singaraja, \\ Indonesia \\ e-mail: wahyuniputri6@gmail.com
}

\begin{abstract}
ABSTRAK
Penelitian ini bertujuan untuk mengetahui; (1) pengaruh pendidikan kewirausahaan terhadap minat mahasiswa untuk berwirausaha pada mahasiswa pendidikan ekonomi undiksha angkatan tahun 2014, dan (2) seberapa besar pengaruh pendidikan kewirausahaan terhadap minat mahasiswa untuk berwirausaha pada mahasiswa pendidikan ekonomi undiksha angkatan tahun 2014. Jenis penelitian ini merupakan penelitian kausalitas, dengan jumlah responden sebanyak 89 mahasiswa jurusan Pendidikan Ekonomi Fakultas Ekonomi Undiksha Angkatan Tahun 2014. Data dikumpulkan dengan menggunakan kuesioner dan dianalisis dengan regresi linier sederhana melalui Statistical Program Social Science (SPSS) 16.0 for windows. Hasil penelitian menunjukkan bahwa: (1) pendidikan kewiraushaaan berpengaruh terhadap minat mahasiswa untuk berwirausaha. Koefisien korelasi yang diperoleh sebesar 0,628 . Memiliki pengaruh positif dan signifikan, (2) dan besarnya pengaruh pendidikan kewirausahaan terhadap minat mahasiswa untuk berwirausaha sebesar $39,5 \%$ sedangkan sisanya sebasar $60,5 \%$ dipengaruhi oleh faktor lain.
\end{abstract}

Kata kunci : pendidikan kewiraushaaan, minat siswa, berwirausaha

\begin{abstract}
The objectives of this study were to know (1) the effect of entrepreneurship education toward students' interest in entrepreneurship in economic education major, Undiksha in 2014, and (2) the percentage of significant effect of entrepreneurship education toward students' interest in entrepreneurship in economic education major, Undiksha in 2014. This study was causal research in which there were 89 students of economic education major as respondent in this study. Data were obtained by using questioner and the data were analyzed through simple linear regression by using Statistical Program Social Science (SPSS) 16.0 for windows. The result shows that (1) there is significant effect of entrepreneurship education toward students' interest in entrepreneurship in which the correlation of the effect is 0,628 . (2) the percentage of the significant effect of entrepreneurship education toward students' interest in entrepreneurship is $39.5 \%$ and the rest is $60,5 \%$ was affected by other factors.
\end{abstract}

Keywords: entrepreneurship education, student's interest, entrepreneurship 


\section{PENDAHULUAN}

\begin{abstract}
Tingkat pengangguran di Indonesia masih tinggi, hal ini disebabkan oleh kualitas sumber daya manusia yang rendah, selain itu sarjana yang berminat menjadi Pegawai Negeri Sipil (PNS) lebih banyak dibandingkan membuat usaha atau bisnis dan membuka lapangan pekerjaan. Hal ini karena minat dan motivasi menjadi wirausaha rendah, fenomena rendahnya minat dan motivasi pemuda Indonesia untuk berwirausaha menjadi pemikiran serius berbagai pihak, baik pemerintah, dunia pendidikan, dunia industri, maupun masyarakat. Berbagai upaya dilakukan untuk menumbuhkan jiwa kewirausahaan terutama merubah mindset para pemuda yang hanya berminat menjadi PNS (Pegawai Negeri Sipil) dan sebagai pencari kerja (job seeker).
\end{abstract}

Sebagai upaya meningkatkan minat wirausaha masyarakat khususnya mahasiswa, perguruan tinggi memberikan mata kuliah pendidikan kewirausahaan. Pendidikan kewirausahaan tidak hanya memberikan landasan teoritis mengenai konsep kewirausahaan tetapi membentuk sikap, perilaku, dan pola pikir (mindset) seorang wirausahawan (entrepreneur). Hal ini merupakan investasi modal manusia untuk mempersiapkan para mahasiswa dalam memulai bisnis baru melalui integrasi pengalaman, keterampilan, dan pengetahuan penting untuk mengembangkan dan memperluas sebuah bisnis.

Pendidikan kewirausahaan adalah pertolongan untuk membelajarkan manusia Indonesia sehingga mereka memiliki kekuatan pribadi yang dinamis dan kreatif untuk menjalankan usahanya sesuai dengan kepribadian bangsa Indonesia yang berdasarkan Pancasila (Wasty Soemanto, 2006;87). Pendidikan kewirausahaan bertujuan untuk membentuk manusia secara utuh, sebagai insan yang memiliki karakter, pemahaman dan keterampilan sebagai wirausaha. Buchari Alma (2003:16) menyatakan bahwa keahlian dan keterampilan wirausaha banyak didapatkan dari pendidikan kewirausahaan. Sikap, perilaku, dan minat ke arah kewirausahaan seorang mahasiswa dipengaruhi oleh pertimbangan atas berbagai aspek mengenai pilihan karir sebagai wirausahawan. Pertimbangan atas pilihan karir tersebut dapat berbedabeda tergantung preferensi terhadap risiko yang akan mereka tanggung kemudian. Mahasiswa yang takut untuk mengambil risiko (risk averter) cenderung untuk memilih menjadi seorang pegawai swasta, atau PNS, sebagai pilihan karir sedangkan bagi mahasiswa yang berani mengambil risiko (risk taker) untuk meninggalkan comfort zone cenderung akan memilih menjadi seorang wirausahawan sebagai pilihan karirnya. Pilihan karir seseorang dipengaruhi beberapa faktor salah satunya adalah Faktor demografis (gender, latar belakang pendidikan orang tua, dan pengalaman bekerja) yang dapat mempengaruhi pilihan karir seseorang untuk menjadi wirausahawan. Pendidikan kewirausahaan dapat membentuk pola pikir, sikap, dan perilaku pada mahasiswa menjadi seorang wirausahawan (entrepreneur) sejati sehingga mengarahkan mereka untuk memilih berwirausaha sebagai pilihan karir.

Mengingat pentingnya pendidikan kewirausahaan bagi masyarakat, khususnya mahasiswa maka Dirjen Pendidikan Perguruan Tinggi (DIKTI) sebagai lembaga yang menaungi pendidikan tingkat universitas memberlakukan program mata kuliah kewirausahaan yang harus diikuti oleh mahasiswa di semua jurusan bidang studi. Pendidikan kewirausahaan diharapkan bukan hanya sebagai kewajiban penyelenggaraan perkuliahan saja, melainkan diperlukan pendekatan sosial dan ekonomi. Pendekatan sosial adalah di mana mahasiswa setelah lulus dari perkuliahan dapat menciptakan lapangan kerja bagi masyarakat sekitarnya. Sedangkan pendekatan ekonomi adalah dengan berwirausaha individu tersebut mampu menghasilkan 
p-ISSN : 2599-1418

e-ISSN : 2599-1426

pendapatan untuk dirinya, orang lain, maupun pemerintah (Murdjianto, 2006).

Pendidikan merupakan hal yang tidak dapat dipisahkan dari kehidupan masyarakat. Pendidikan merupakan kegiatan yang sangat kompleks, hampir seluruh aspek kehidupan manusia berhubungan dengan proses pendidikan. Melalui pendidikan, karakter dan sifat manusia dapat dibentuk agar menjadi manusia yang mempunyai keterampilan dan kecerdasan. Pendidikan dapat dimulai dari lingkungan keluarga, masyarakat dan pemerintah. Hal ini sesuai dengan pernyataan Redja Mudyaharjo (2012), pendidikan merupakan usaha sadar yang dilakukan oleh keluarga, masyarakat, dan pemerintah, melalui kegiatan bimbingan, pengajaran dan latihan yang berlangsung di sekolah dan di luar sekolah sepanjang hayat, untuk mempersiapkan peserta didik agar dapat memainkan peranan dalam berbagai lingkungan hidup secara tepat di masa yang akan datang. Menurut Sugihartono dkk. (2007:3), pendidikan adalah suatu usaha yang dilakukan secara sadar untuk mengubah tingkah laku manusia baik secara individu maupun kelompok untuk mendewasakan manusia melalui upaya pengajaran dan pelatihan sehingga mempunyai kemampuan untuk bertanggung jawab terhadap segala perbuatannya. Pendidikan bisa ditempuh dengan jalur formal dan in formal, pendidikan formal merupakan pendidikan di sekolah maupun di perguruan tinggi yang di peroleh secara teratur, sistematis, bertingkat, dan dengan mengikuti syarat-syarat yang jelas. Sebagai lembaga pendidikan formal, sekolah yang lahir dan berkembang secara efektif dan efisien dari dan oleh serta untuk masyarakat, merupakan perangkat yang berkewajiban memberikan pelayanan kepada generasi muda dalam mendidik warga negara. Menurut Undang-Undang No 20 Tahun 2003 pendidikan formal didefinisikan sebagai jalur pendidikan yang terstruktur dan berjenjang yang terdiri atas pendidikan dasar, penddikan menengah, dan pendidikan tinggi. Pada
Jurnal Pendidikan Ekonomi Undiksha

Volume 9 No.1 Tahun: 2017

umumnya lembaga formal adalah tempat yang paling memungkinkan seseorang meningkatkan pengetahuan, dan paling mudah untuk mengubah generasi muda yang dilaksanakan oleh pemerintah dan masyarakat (Ahmadi dan Uhbiyati 2007 :162). Pendidikan in formal menurut Undang-Undang No 20 Tahun 2003 adalah jalur pendidikan keluarga dan lingkungan yang yang berbentuk kegiatan secara mandiri (Suprijanto, 2005: 6-8). Dalam lembaga pendidikan informal kegiatan pendidikan tanpa organisasi yang ketat tanpa adanya program waktu, (tak terbatas), dan tanpa adanya evaluasi. Adapun alasanya di atas pendidikn in formal ini tetap memberikan pengaruh kuat terhadap pembentukan pribadi seseorang/peserta didik.

Pemerintah telah mengeluarkan Instruksi Presiden Nomor 4 Tahun 1995 tentang Gerakan Nasional Memasyarakatkan dan Membudayakan Kewirausahaan. Instruksi ini mengamanatkan kepada seluruh masyarakat dan bangsa Indonesia untuk mengembangkan program-program kewirausahaan. Pemerintah menyadari betul bahwa dunia usaha merupakan tulang punggung perekonomian nasional, sehingga harus diupayakan untuk ditingkatkan secara terus menerus. Melalui gerakan ini diharapkan karakter kewirausahaan akan menjadi bagian dari etos kerja masyarakat dan bangsa Indonesia, sehingga dapat melahirkan wirausahawanwirausahawan baru yang handal, tangguh, dan mandiri. Menurut pendapat Suherman (2008), hal itu sangat penting mengingat bahwa sebenarnya aktivitas kewirausahaan tidak hanya berada dalam tataran microeconomy.

Kewirausahaan adalah suatu kemampuan menciptakan kegiatan usaha. Kemampuan menciptakan dan memerlukan adanya kreativitas dan inovasi dari yang sudah ada sebelumnya.Kemampuan berwirausaha yang kreatif dan inovatif dapat dijadikan dasar, kiat, dan sumber daya untuk mencari peluang menuju sukses (Suryana, 2006: 2). Peluang sukses di 
p-ISSN : 2599-1418

e-ISSN : 2599-1426

masa depan dapat diraih apabila seorang wirausaha benar-benar memanfaatkan peluang dengan baik dan mempunyai disiplin diri. Sedangkan menurut Zimmerer dalam Suryana (2006: 14) Kewirausahaan merupakan penerapan kreativitas dan inovasi untuk memecahkan masalah dan memanfaatkan peluang yang dihadapi. Kreativitas diartikan sebagai kemampuan mengembangkan ide-ide dan menemukan cara-cara baru dalam memecahkan masalah, sedangkan inovasi diartikan sebagai kemampuan menerapkan kreativitas untuk memecahkan masalah dan peluang untuk meningkatkan kekayaan hidup. Stoner dalam Jamal Ma'mur Asmani (2011) menyatakan bahwa pada dasarnya kewirausahaan bergerak dari kebutuhan dasar manusia untuk berprestasi. Kewirausahaan dibentuk pada diri seseorang melalui pendidikan atau pelatihan. Pendidikan atau pelatihan kewirausahaan merupakan proses pembelajaran konsep dan skill untuk mengenali peluang-peluang yang orang lain tidak mampu melihatnya.

Pendidikan kewirausahaan dapat didefinisikan sebagai usaha yang dilakukan lembaga pendidikan untuk menanamkan pengetahuan, nilai, jiwa dan sikap kewirausahaan kepada mahasiswa dan peserta didik guna membekali diri menjadi manusia yang mandiri, kreatif dan inovatif. Hal ini juga bertujuan untuk menciptkan wirausahawirausaha baru yang handal dan berkarakter dan dapat meningkatkan kesejahteraan masyarakat. Pendidikan kewirausahaan adalah senjata penghancur pengangguran dan kemiskinan, dan menjadi tangga menuju impian setiap masyarakat untuk mandiri secara finansial, memiliki kemampuan membangun kemakmuran individu, sekaligus ikut membangun kesejahteraan masyarakat (Jamal Ma'mur Asmani: 2011). Menurut Agus Wibowo (2011: 76), terdapat dua cara untuk menanamkan mental kewirausahaan kepada para mahasiswa di kampus. Pertama, mengintegrasikan pendidikan kewirausahaan ke dalam
Jurnal Pendidikan Ekonomi Undiksha

Volume 9 No.1 Tahun: 2017

kurikulum. Kedua, aktivitas ekstrakurikuler mahasiswa perlu dikemas sistemik dan diarahkan untuk membangun motivasi dan sikap mental wirausaha.

Pendidikan kewirausahaan secara umum adalah proses pendidikan yang menerapkan prinsip-prinsip dan metodologi ke arah pembentukan kecakapan hidup (life skill) pada peserta didiknya melalui kurikulum terintegrasi yang dikembangkan di sekolah maupun diperguruan tinggi. Minat adalah kecenderungan yang menetap dalam subyek untuk merasa tertarik pada bidang tertentu dan merasa senang berkecimpung dalam hal itu (Winkel. Widiyatnoto, 2013:5). Menurut Suhartini (2011:44), minat adalah seperangkat mental yang terdiri dari suatu campuran perasaan, harapan, pendirian, kecenderungan yang mengarahkan individu kepada suatu pilihan tertentu. Sedangkan menurut Hurlock (1993:144), minat merupakan suatu dorongan yang timbul dari dalam diri seseorang untuk melakukan apa yang mereka inginkan dan mereka bebas memilih.

Sedangkan berwirausaha seperti yang dikemukakan oleh Coulter (Suryana dan Bayu, 2011:24) dan Sethi (Bilic at al., 2011:116), yaitu melakukan kegiatan pembentukan, atau menumbuhkan suatu bisnis yang menyediakan barang dan jasa baru yang unik dan inovatif, serta menciptakan lapangan kerja yang berorientasi pada perolehan keuntungan dan memberi kontribusi pada pendapatan nasional dan pembangunan ekonomi secara keseluruhan. Minat wirausaha adalah kemampuan untuk memberanikan diri dalam memenuhi kebutuhan hidup serta memecahkan permasalahan hidup, memajukan usaha atau menciptakan usaha baru dengan kekuatan yang ada pada diri sendiri (Yanto dalam Hermina, dkk. 2011:140).

Minat berwirausaha adalah keinginan, ketertarikan serta kesediaan untuk bekerja keras atau berkemauan keras untuk berdikari atau berusaha untuk memenuhi kebutuhan hidupnya tanpa merasa takut dengan risiko yang 
akan terjadi, serta berkemauan keras untuk belajar dari kegagalan(Fu'adi, dkk., (2009:92), Sedangkan menurut Santoso (Fu'adi, dkk., 2009:92), minat wirausaha adalah gejala psikis untuk memusatkan perhatian dan berbuat sesuatu terhadap wirausaha itu dengan perasaan senang karena membawa manfaat bagi dirinya maupun orang lain. Minat berwirausaha dapat dilihat sebagai niat untuk menciptakan suatu organisasi atau usaha baru atau sebagai prilaku yang berani mengambil risiko untuk memulai bisnis baru (Edy Dwi Kurnianti, 2015). Minat berwirausaha adalah pilihan ativitas seseorang karena merasa tertarik, senang dan berkeinginan untuk berwirausaha serta berani mengambil risiko untuk meraih kesuksesan (Suryana,2011). Menurut Santoso dalam Maman Suryaman (2006: 22) minat wirausaha adalah gejala psikis untuk memusatkan perhatian dan berbuat sesuatu terhadap wirausaha itu dengan perasaan senang karena membawa manfaat bagi dirinya. Inti dari pendapat tersebut adalah pemusatan perhatian yang disertai rasa senang. Menurut Aris Subandono, minat wirausaha adalah kecenderungan hati dalam diri subjek untuk tertarik menciptakan suatu usaha yang kemudian mengorganisir, mengatur, menanggung risiko dan mengembangkan usaha yang diciptakannya tersebut. Menurut Edy Dwi Kurniati (2015: 71-72) yang memepengaruhi minat berwirausaha secara garis besar dapat diklompokkan menjadi dua faktor, yaitu: pertama faktor Intrinsik adalah faktor-faktor yang timbul karena penagruh rangsangan dari dalam individu itu sendiri yaitu pendapatan, Harga diri, perasaaan senang. Faktor Ekstrinsik adalah faktor-faktor yang mempengaruhi individu karena pengaruh rangsangan dari luar. Faktorfaktor yang mempengaruhi individu karenan pengaruh rangsangan dari luar yaitu lingkungan keluarga, lingkungan masyarakat, peluang, dan pendidikan.

Minat berwirausaha tidak dibawa sejak lahir tapi tumbuh dan berkembang sesuai dengan faktor-faktor yang
Jurnal Pendidikan Ekonomi Undiksha

Volume 9 No.1 Tahun: 2017

mempengaruhi. Faktor yang mempengaruhi tumbuhnya keputusan untuk berwirausaha merupakan hasil interaksi dari beberapa faktor yaitu karakter kepribadian seseorang dan lingkungannya. Menurut Lambing dan Kuehl (2007), hasil penelitian terbaru menunjukkan ada empat hal yang mempengaruhi keputusan berwirausaha, yaitu diri pribadi, lingkungan budaya, kondisi sosial, dan kombinasi dari ketiganya. Sedangkan menurut Hisrich, et al. (2005: 18) dan Alma (2010: 12), faktor yang mempengaruhi minat wirusaha adalah lingkungan pendidikan, kepribadian seseorang dan lingkungan keluarga.

Berdasarkan hasil wawancara yang peneliti lakukan terhadap 89 responden (mahasiswa Prodi Pendidikan Ekonomi angakatan 2014) yang digunakan sebagai sampel penelitian menunjukkan bahwa sejumlah 58 responden $(65,16 \%)$ mahasiswa jurusani Pendidikan Ekonomi angkatan 2014 kurang berminat untuk menjadi wirausahawan. Hal ini dapat dilihat dari jawaban yang diberikan responden yang menyatakan bahwa mereka tidak berani mengambil resiko, dan lebih tertarik untuk menjadi PNS serta bekerja di perusahaan swasta seperti di Bank dan perusahaan lainnya. Oleh karena itu, perlu adanya penelitian untuk mengidentifikasi faktor yang mendorong minat berwirausaha mahasiswa mengingat pentingnya kewirausahaan bagi kesejahteraan ekonomi dan sosial.

Sesuai dengan rumusan masalah di atas, maka tujuan penelitian ini adalah untuk mengetahui apakah ada pengaruh pendidikan kewirausahaan terhadap minat mahasiswa untuk berwirausaha dan seberapa besar pengaruh pendidikan kewirausahaan terhadap minat mahasiswa untuk berwirausaha.

\section{METODE}

Penelitian ini dilakukan di Jurusan Pendidikan Ekonomi, Fakultas Ekonomi Universitas Pendidikan Ganesha angkatan tahun 2014 dengan fokus pengamatan pada pendidikan kewirausahaan khususnya mata kuliah 
p-ISSN : 2599-1418

e-ISSN : 2599-1426

kewirausahaan terhadap minat mahasiswa untuk berwirausaha. Jenis penelitian ini adalah penelitian kausalitas yang digunakan untuk megetahui hubungan sebab-akibat dari variabel yang diteliti. Penelitian ini terdiri dari dua variabel yaitu variabel bebas dan variabel terikat.

Data dikumpulkan dengan cara wawancara dan menyebarkan koesioner kepada responden. Data yang digunakan dalam penelitian ini berdasarkan sumbernya adalah data primer yaitu hasil jawaban responden yang diperoleh dengan menggunakan kuisioner. Populasi ialah terdiri atas sekumpulan objek yang menjadi pusat perhatian, yang dari padanya tekandung informasi yang ingin diketahui. Menurut Soegeng (2006) populasi adalah keseluruhan dari sasaran penelitian. Secara sederhana, populasi adalah keseluruhan objek penelitian. Adapun populasi yang dijadikan objek penelitian ini adalah mahasiswa Jurusan Pendidikan Ekonomi angkatan tahun 2014, yang berjumlah 89 mahasiswa.

Apabila objek atau populasi kurang dari 100, lebih baik diambil semua sehingga penelitiannya merupakan penelitian populasi. Karena jumlah populasi kurang dari 100, maka peneliti menjadikan semua populasi sebagai sampel penelitian. jadi penelitian ini merupakan penelitian populasi. (Arikunto, 2002:12),

Sebelum peneliti menyebar kuisioner kepada responden peneliti terlebih dahulu melakukan uji validitas dan uji reliabilitas. Ada dua macam validitas sesuai dengan cara pengujiannya, yaitu validitas eksternal dan validitas internal. Pada validitas eksternal, rumus yang akan digunakan adalah rumus Korelasi Product Moment. Kemudian untuk validitas internalnya akan digunakan analisis butir, dimana analisis ini digunakan untuk menguji validitas setiap butir soal. Dengan diperolehnya indeks validitas butir setiap butir dapat diketahui dengan pasti butirbutir manakah yang tidak memenuhi syarat, sehingga peneliti dapat mengganti ataupun merevisi butir-butir
Jurnal Pendidikan Ekonomi Undiksha

Volume 9 No.1 Tahun: 2017

yang dimaksud (Arikunto, 2006). Reliabilitas adalah alat untuk mengukur suatu kuesioner yang merupakan indikator dari variabel atau konstruk (Ghozali, 2006). Suatu kuesioner dikatakan handal atau reliabel jika jawaban seseorang terhadap pernyataan adalah konsisten atau stabil dari waktu ke waktu. Variabel akan dikatakan reliabel apabila hasil ( Cronbach Alpha) > 0,60 adalah reliabilitas (Nunally, 1967 dalam Ghozali, 2006 24). Cara menghitung reliabilitas suatu kuesioner denagn menggunakan rumus cronbach alpha karena merupakan salah satu koefisien realibilitas yang paling sering digunakan. Setelah data yang terkait dengan masalah yang dikumpulkan, maka untuk selanjutnya diadakan penganalisisan upaya pemecahan masalah-masalah yang telah dirumuskan sebelumnya. Dalam penelitian ini alat analisis data yang digunakan adalah statistik infrensial yang bertujuan untuk menguji hipotesis dengan menggunakan Regresi Linier Sederhana melalui program komputer SPSS 16.0 Analisis Regresi sederhana ini digunakan untuk mengetahui arah dan besarnya pengaruh pendidikan kewirausahaan terhadap minat mahasiswa untuk berwirausaha yang perhitungannya menggunakan program SPSS.

Selain melakukan uji t peneliti juga melakukan uji normalitas dan Uji Heteroskedastisitas. Uji normalitas bertujuan untuk mengetahui apakah data yang digunakan untuk penelitian mempunyai ditribusi yang normal atau tidak (Imam, 2011:160). Hipotesis yang diajukan adalah Ho (Hipotesis Nol) yang artinya data $X$ berdistribusi normal dan HA (Hipotesis Alternatif) yang artinya data $X$ tidak distribusi normal. Pengambilan keputusannya adalah jika Sig. $(p)<0,05$ maka Ho ditolak atau variabel tidak terdistribusi secara normal. Sedangkan Model regresi yang baik adalah homoskedastisitas atau tidak terjadi heteroskedastisitas. Cara untuk mendeteksi ada atau tidaknya heteroskedastisitas yaitu dengan melihat pada Scatterplot. Apabila pada 
p-ISSN : 2599-1418

e-ISSN : 2599-1426

Scatterplot membentuk sebuah pola maka tidak terjadi heterokedastisitas sedangkan apabila tidak membentuk sebuah pola atau menyebar maka tidak terjadi heterokedastisitas.

Setelah dilakukan uji normalitas, dan selanjutnya dilakukan uji hipotesis. Uji hipotesis ini bertujuan untuk membuktikan kebenaran dari hasil penelitian ini. Untuk menganalisis data hasil penelitian ini yaitu analisis statistic uncorrelated data/independent sampel ttest. Dalam penelitian ini menggunakan satu variabel bebas yaitu pendidikan kewirausahaan. Adapun tujuan dari hipotesis dalam penelitiian ini yaitu untuk mengetahui pengaruh pendidikan kewirausahaan terhadap minat ber viraus@iha.

Kriteria pengujian

Mer ımuskan statistik:

$\mathrm{H} 0: P_{X Y}=0$ artinya tidak ada pengaruh Pentidikan kew irausahaan terhadap minat berwirausaha.

Ha: $P_{x y} \neq 0$ cartinya ada pengaruh pendidikan kew irausahaan terhadap minat berwirausaha.
Jurnal Pendidikan Ekonomi Undiksha

Volume 9 No.1 Tahun: 2017
Kriteria Pengujian hopotesis:

Jika $t_{\text {hitung }}>t_{\text {tabel }}$, berarti menolak $\mathrm{H} 0$, ada pengaruh pendidikan kewirausahaan s ecara signifikan terhadap minat berwirausa ha denagn taraf Signifikansi $a=0,05$.

Jika $\mathrm{t}_{\text {hitung }}<t_{\text {tabel }}$, berarti menerima $\mathrm{HO}$, tidak ada nengarıı pendidikan kewirausahaan secara signifikan terhadap minat berwirausaha denagn taraf signifikansi $a=0,05$.

\section{HASIL DAN PEMBAHASAN hasil}

Data yang berhasil dikumpulkan dari koesioner yang disebarkan dan setelah diolah dengan spss 16.0 for windows menunjukkan bahwa pendidikan kewiraushaaan berpengaruh secara signifikan terhadap minat mahasiswa pendidikan ekonomi UNDIKSHA angkatan tahun 20014. Untuk melihat perhitungan uji $t$ yang menggunakan spss dapat di lihat pada tabel1.

Tabel 1. Hasil Uji “t” Dan Perhitungan Koefisen Beta

\begin{tabular}{|c|c|c|c|c|c|c|}
\hline \multirow[b]{2}{*}{ Model } & \multirow{3}{*}{ (Constant) } & \multicolumn{2}{|c|}{$\begin{array}{l}\text { Unstandardized } \\
\text { Coefficients }\end{array}$} & \multicolumn{2}{|c|}{$\begin{array}{l}\text { Standardized } \\
\text { Coefficients }\end{array}$} & \multirow[b]{2}{*}{ Sig. } \\
\hline & & B & Std. Error & Beta & $t$ & \\
\hline \multirow[t]{2}{*}{1} & & 10.804 & 3.873 & & 2.789 & .006 \\
\hline & $X$ & .639 & .085 & .628 & 7.535 & .000 \\
\hline
\end{tabular}

Berdasarkan tabel 1, pengujian hipotesis dilakukan dengan jumlah sampel 89 mahasiswa, sehingga dapat diperoleh $\mathrm{df}=\mathrm{n}-\mathrm{k}=89-2=87$, sehingga $t_{\text {tabel }}$ dengan df 87 adalah sebesar 1,98 berdasarkan analisis pada tabel 4.2. memperlihatkan bahwa variabel pendidikan ke wirausahaan berpengaruh secara signifikan terhadap minat berwirausaha, karena nilai $t_{\text {hitung }}=$ $7.535>t_{\text {tabel }}=1.98$ atau $\mathrm{p}$ value $=$ $0.000<a=0.05$ maka Ho ditolak.
Dengan demikian, variabel pendidikan kewirausahaan memiliki pengaruh yang signifikan terhadap minat berwirausaha pada Mahasiswa Pendidikan Ekonomi Undiksha Angkatan Tahun 2014 dapat digambarkan dengan persamaan regresi linier sederhana sebagai berikut.

$\hat{Y}=a+b x$
$\hat{Y}=10.804+0,639 x$
dimana:
$\hat{Y}=$ Minat Berwirausaha
$X=$ Pendidikan Kewirausahaan 
Tabel 2 Hasil Perhitungan Koefisien Determinasi (

\begin{tabular}{|c|c|c|c|c|}
\hline Model & $\mathrm{R}$ & R Square & $\begin{array}{l}\text { Adjusted } \\
\text { Square }\end{array}$ & $\begin{array}{c}\text { R Std. Error of } \\
\text { the Estimate }\end{array}$ \\
\hline 1 & $.628^{a}$ & .395 & .388 & 4.74059 \\
\hline
\end{tabular}

Berdasarkan tabel 2 besarnya nilai korelasi/hubungan $(R)$ yaitu sebesar 0,628 dan dijelaskan besarnya prosentase pengaruh variabel bebas terhadap variabel terikat yang disebut koefisien determinasi yang merupakan hasil dari penguadratan $R$. Dari output terseput diperoleh koefisien determinasi $\left(R^{2}\right)$ sebesar 0,395 yang mengandung Kengertian bahwa pengaruh variabel bebas (pendidikan kewirausahaan) terhadap variabel terikat (minat berwirausaha) adalah sebesar 39,5\%, dan sisanya $60,5 \%$ dipengaruhi oleh variabel yang lain.

\section{PEMBAHASAN}

Berdasarkan hasil perhitungan regresi sederhana dan uji t memberikan implikasi bahwa pendidikan kewirausahaan berpengaruh positif terhadap minat berwirausaha. Besarnya keeratan hubungan antara variabel pendidikan kewirausahaan dan minat berwirausaha sebesar 0,628 atau 62,8 $\%$. Besarnya sumbangan pengaruh yang diberikan variabel pendidikan kewiraushaan terhadap minat berwirausaha adalah sebesar 0,395 atau $39,5 \%$ yang mempengaruhi minat berwirausaha mahasiswa.

Hasil penelitian ini sejalan dengan teori yang dinyatakan oleh Edy Dwi Kurnianti (2015) yang menyatakan bahwa faktor yang mempengaruhi minat berwirausaha terdiri dari dua aspek yaitu aspek intrinsik (pendapatan, harga diri, dan perasaaan senang) dan aspek ekstrinsik (lingkungan keluarga, lingkungan masyarakat dan pendidikan). Hasil penelitian ini juga mendukung teorinya Buchari Alma (2009), menyatakan bahwa latar belakang timbulnya minat berwiraushaa adalah pendidikan, lingkungan keluarga, nilainilai personal, usia, dan riwayat pekerjaan. Selain itu juga menyatakan bahwa keahlian dan keterampilan wirausaha banyak didapatkan dari pendidikan kewirausahaan.

\section{SIMPULAN DAN SARAN simpulan}

Berdasarkan hasil penelitian dan pembahasan, maka dapat disimpulkan bahwa pendidikan kewirausahaan berpengaruh signifikan secara terhadap minat berwirausaha pada Mahasis awa Pendidikan Ekonomi Undiksha hasisatan Tahun 2014. Hal tẹssha Angkâfân ditunjukan dari hasil anasebut dapat menunjukkan bahwa nilai lisis $t_{\text {tes }}$ yang $>t_{\text {tabel }}=1.98$ atau $p$ vall $t_{\text {hitung }}=7.535$ $=0.05$. Besarn ya pengaruh $=$ pe. odjolikan kewirausahaan terhadap minat berwirausaha adalah sebesar 0,395 atau $39,5 \%$ yang mempengaruhi minat berwirausaha mahasiswa.

\section{saran}

Berdasarkan simpulan di atas maka dapat dikemukakan beberapa saran sebagai berikut.

1) Bagi lembaga hasil penelitian ini menunjukkan bahwa pendidikan kewiraushaaan berpengaruh terhadap minat berwirausha pada mahasiswa pendidikan ekonomi UNDIKSHA angkatan tahun 2014. Oleh sebab itu, penulis memberikan saran kepada lembaga undiksha untuk tetap memperhatikan apa yang dibutuhkan mahasiswa agar dapat meningkatkan minat berwirausaha mahasiswa.

2) Dan bagi peneliti lain yang bermaksud melakukan penelitian di bidang pendidikan kewiruashaaan diharapkan untuk mengembangkan penelitian ini dengan menambah variabel bebasnya yang diduhga kuat dapat mempengaruhi minat berwirausaha mahasiswa misalnya seperti pendapatan, harga diri, perasaan senang, lingkungan 
keluarga, dan lingkungan masyarakat.

\section{DAFTAR PUSTAKA}

Adi, Susanto. 2002. Kewirausahaan. Jakarta: Galia Indonesia.

Alma, B. 2003. Kewirausahaan. Bandung: Alfabeta. 2006. Kewirausahaan Untuk Mahasiswa dan Umum. Bandung: Alfabeta.

Andreas, Harefa. 2004. Inovasi Kewirausahaan Utnuk Semua Orang. Jakarta: Gramedia Pustaka Utama.

Aprilianty, Eka. 2012. Pengaruh Keppribadian Wirausaha, Pengetahuan Kewirausahaan, Dan Lingkungan Terhadap Minat Berwirausaha Siswa SMK Jurnal, Pendidikan Vokasi. Pangkalan Bun, Kalimantan Tengah: SMK Muhammadiyah Vol 2, Nomor 3, November 2012, 311-324.

Assauri, Sofjan. 2007. Manajemen Pemasaran, Dasar, Konsep dan Strategi. Jakarta: PT. Rajaggrafinda Persada.

Arikunto, Suharsimi. 2002. Prosedur Penelitian suatu pendekatan praktis. Jakarta: PT. Rineka Cipta.

2006. Prosedur Penelitian Kualitatif. Edisi Ketigabelas. Jakarta: PT. Rineka Cipta.

Aritonang, Keke Taruli. 2013. Pengintegrasian Pendidikan Kewirausahaan Melalui Pembelajaran Terpadu Berbagai Disiplin IImu. Jurnal Pendidikan Penabur. Vol.12 (21), pp: 63-77.

Basrowi. 2011. Kewirausahaan untuk Perguruan Tinggi. Bogor: Ghalia Indonesia.

Basrowi. 2014. Kewirausahaan untuk Perguruaan Tinggi. Bogor: PT. Ghalia Indonesia.

Daryanto. 2012.2 Pendidikan Kewirausahaan. Yogyakarta: Gava Media.

Fu'adi, Isky Fadli, Budiarso Eko, dan Murdani. 2009. Hubungan
Minat Berwirausaha Dengan

Prestasi Praktik Kerja Industri

Siswa Kelas XII Teknik

Otomotif SMK Negeri 1

Adiwerna Kabupaten Tegal

Tahun Ajaran 2008/2009.

Semarang: Program Studi

Pendidikan Teknik Mesin

Universitas Negeri Semarang

Volume 9, Nomor 2,

Desember 2009, 92-98.

Emzir. 2010. Metodelogi Pendidikan: Kuantitatif dan Kualitatif. Jakarta: Rajawali Pers.

Gozali, Imam. 2006. Aplikasi Analisis Multivariate Dengan SPSS.

Cetakan Keempat. Badan

Penerbit Universitas Diponegoro, Semarang.

H.A. Rusdiana. (2014). Kewirausahaan Teori Dan Prakthadap Minatik. Bandung: CV PUSTAKA SETIA

Hermina, Utin Nina, Syarifah Novieyana \& Desvira Zain. 2011. Pengaruh Mata Kuliah Kewirausahaan Terhadap Minat Mahasiswa Menjadi Wirasuaha Pada Prod=Gram Studi Administrasi Bisnis Politeknik Negeri Pontianak Jurnal Eksos. Pontianak: Jurusan Administrasi Bisnis Politeknik Negeri Vol. 7 No 2 Issn 1693-9093 Jul. 2011, 130-141.

Jamal Ma'mur Asmani. 2011. Sekolah Entrepreneur. Yogyakarta: Harmoni.

Joko, Sutrosno. 2003. Pengembangan Pendidikan Berwawasan Kewirausahaan Sejak Usia Dini. Jakarta: Depdiknas.

Kasmir. 2006. Kewirausahaan. Jakarta: PT. Rajagrafindo Persada. 2011. Kewirausahaa. Jakarta: PT. Rajagrafindo Persada. 2013. Kewirausahaan: Edisi Revisi. Jakarta: Rajawali Press.

Kemendiknas. 2010. Pengembangan Pendidikan Kewirausahaan. Jakarta. 
Kurnianti, Edy Dwi. 2015. Kewirausahaan Industri. Yogyakarta: Depublish.

Lieli, Suharti dan Sirine Hani. 2011. Faktor-Faktor Yang Berpengaruh terhadap Niat Kewirausahaan

(Entrepreneurial Intention). Jurnal Manajemen dan Kewirausahaan. Vol.13, No. 2, pp. 124-134.

Lestari, B.R dan Trisnadi Wijaya. 2012. Pengaruh Pendidikan Kewirausahaan terhadap Minat Berwirausaha Mahasiswa di STIE MDP, STMIK MDP, Dan STIE MUSI. Forum Bisnis dan Kewirausahaan Jurnal IImiah STIE MDP. Vol. 1 No. 02, pp: 112-119.

Meredith, Gooeffrey G. 2002. Kewirausahaan: Teori dan Praktik. Jakarta: IKAPI.

Murdiyanto, Ari. 2012. Peningkatan Minat Wirasuaha Melalui Model Sinektik Pada Siswa Kelas XII AK2 di SMK ABDI NEGARA Muntilan. Skripsi (tidak diterbitkan). Jurusan Psikologi Pendidikan dan Bimbingan Fakultas IImu Pendidikan Universitas Negeri Yogyakarta.

Murdjianto dan Aliaras Wahid. 2006. Membangun Karakter Dan Kepribadian Kewirausahaan. Yogyakarta: Graha Ilmu.

Patria, Paulus Adhitama. 2014. FaktorFaktor Yang Mempengaruhi Minat Berwirausaha (Studi Kasus Mahasiswa Fakultas Ekonomika Dan Bisnis UNDIP. Sripsi (tidak (Enterpreneurial Intention)( Studi Terhadap Mahasiswa Universitas Kristen Satya Wacana, Salatiga) Jurnal Manajemen Dan Kewirausahaan. Salatiga: Fakultas Ekonomika Dan Bisnis, Univesitas Kristen diterbitkan). Jurusan IESP Semarang.

Redja Mudyaharjo. (2012). Pengantar Pendidikan. Jakarta: PT. Rajagrafindo Persada.

Schuk, Hale H.et al. 2010. Motivasi Dalam Pendidikan: Teori, Penelitian, dan Aplikasi. New Jersey: Prentice-Hall, Inc.

Siswadi, Yudi. 2013. Analisis Faktor Internal, Faktor Eksternal dan Pembelajaran Kewirausahaan yang Mempengaruhi Minat Mahasiswa dalam Berwirausaha. Jurnal Manajemen \& Bisnis. Vol 13 No. 01, pp: 1-17.

Soegeng, Ay. 2006. Dasar-Dasar Penelitian Bidang Sosial, Psikologi, dan pendidikan. Semarang: IKIP PGRI Semarang Press.

Soemanto, Wasty. 2006. Pendidikan Wiraswasta. Jakarta: Bumi Aksara.

Stokes, D. 2007. Puttingenterprenurship Into Marketing, Journal of Research in Marketing and Enterprenurship: Vol. 2 No. 1: Spring 2000.

Sugihartono dkk. (2007). Psikologi Pendidikan.Yogyakarta:UNY Press

Sugiyono. (2012). Metode Penelitian Kuantitatif, Kualitatif, dan $R \& D$. Bandung: CV ALFABETA.

Suhartini, Lieli dan Hani Sirine. 2011. Faktor-Faktor Yang Berpengaruh Terhadap Niat Kewirausahaan

Satya Wacana Vol. 13, No 2, 2011.

Suryaman, Maman. (2006) Minat Berwirausaha Pada Mahasiswa Pendidikan Teknik Elektro Fakultas Teknik Universitas Negeri Semarang, Skripsi (tidak diterbitkan). 
Fakultas Teknik - Universitas Negeri Semarang.

Suryana, Yuyus. 2003. Kewirausahaan. Pedoman Praktis, Kiat, dan Proses Menuju Sukses. Jakarta: Salemba Empat.

2006. Kewirausahaan Pedoman Praktis, Kiat dan Proses Menuju Sukses Edisi 3. Jakarta: Salemba Empat. 2011. Kewirausahaan: Pendekatan Karakteristik Wirausahawan Sukses. Jakarta: Prenada Media Group.

Suryana, Yuyus dan Kartib Bayu. 2011. Kewiraushaaan: Pendekatan Karakteristik Wirausahawan Sukses. Jakarta: Kencana Prenada Media Group.

Sumarno, Firdaus. 2012. Pengaruh Prestasi Praktik Kerja Industri, Prestasi Mata Pelajaran Kewirausahaan, dan Konsep Diri terhadap Minat Berwirausaha Siswa Kelas Xii Smk Negeri 1 Kandeman Batang. Skripsi (tidak diterbitkan). Program Studi Pendidikan Teknik Elektro Fakultas Teknik Universitas Negeri Yogyakarta.

Utomo, Bambang Budi., Mashudi dan Nuraini. 2014. Pengaruh Pendidikan Kewirausahaan dalam keluarga dan di Sekolah terhadap Minat Berwirausaha. Jurnal Pendidikan dan Pembelajaran. Vol. 3 (4), pp: 1-15.

Widiyatnoto, Erfikas. 2013. Pengaruh Jiwa Kewirausahaan Dan Budaya Keluarga Terhadap Minat Berwirausaha pada Siswa SMK N 1 Winosari dan SMK N 2 Winosari di Kabupaten Gunung Kidul. Universitas Negeri Yogyakarta 
